\title{
Morocco and Western Sahara
}

\section{by Chad McCoull [ Mine Action Information Center ]}

B $y$ the time Spain abandoned its Western Saharan claims in 1976, three warring factions had emerged, taking up arms over custody of the territory: Morocco seeking southern annexation, Mauritania seeking northern annexation, and Saharan natives seeking to establish their own nation, the Saharawi Arab Democratic Republic. Consolidating control over their Saharan homeland with a guerrilla army, these natives united as the Frente Popular por la Liberación de Saguia el Hamra y Río de Oro, better known as the Polisario. The Polisario rebels eliminated the weak Mauritanian forces by 1979 , at which point Morocco was able to seize control of Western Sahara's southern region. In order to prevail during the deadlocked standoff with the Polisario, Morocco pursued a military strategy involving the construction of six berms, or three-foot tall (one-meter) earthen walls, supplemented with landmines. The berms divide the middle of the territory, extending 1,690 miles $(2,700 \text { kilometers })^{1}$ from the southwest to northeast of the Western Sahara. When the United Nations imposed an end to hostilities in 1991, Morocco and the Polisario dropped their weapons, but they have yet to arrive at a peaceful reconciliation.

\section{Mine Problem}

Over a period of three years after the onset of the war, Morocco purchased US $\$ 6.5$ million worth of VS-50 anti-personnel and VS-1.6 anti-tank mines. ${ }^{2}$ Though Morocco never manufactured or exported mines, both Morocco and the Polisario imported and used an unidentified number of landmines, artillery shells and ordnance during the 15-year conflict. Within the formal boundaries of their country, mines do not threaten the safety of most Moroccans today. Authorities believe, however, that just under 39,000 square miles $(100,000$ square kilometers) of the disputed Western Sahara contain many varieties of unexploded ordnance. ${ }^{3}$ The bulk of the mines are buried along the berm, comprising the longest uninterrupted minefield in the world. ${ }^{4}$ In regions far from the berm, explosive remnants of war like cluster munitions, endanger civilians living in Polisario-controlled areas. Landmines and other ERW not only prevent inhabitants from living comfortably on the land, they also prevent the homecoming of 160,000 Saharawi refugees currently residing in Algeria. ${ }^{4}$
Organizations have had difficulty keeping precise mine incident records in Western Sahara, but surveys indicate that from 2000 to 2006, minerelated casualties ranged anywhere from one death in one 12-month survey period to 51 deaths in another. ${ }^{5}$ The Swiss Foundation for Landmine Victim Aid has repeatedly found children age 18 and under to be the most likely population to be injured by landmines in Western Sahara. It is estimated that only 32 percent of disabled Moroccan children, ages 4 to 15 , attend school. ${ }^{6}$ Of the 5 percent of Moroccans with a disability, 12 percent are employed. ${ }^{6}$

\section{Mine Action}

At the time Morocco and the Polisario agreed to discontinue their use of landmines in 1991, the United Nations established MINURSO, also known as Mission des Nations Unies pour l'Organisation d'un Référendum au Sahara Occidental. In order to maintain peace and improve the environment on both sides of the berms, many of MINURSO's mission objectives involve mine action: marking mines and UXO, publishing maps for safe passage throughout the territory, destroying and fencing minefields and promoting mine-risk education for locals and refugees.

Though inconsistencies in recordkeeping make it difficult to determine MINURSO's impact thus far in Western Sahara, one estimate finds that from 1999 to 2005 MINURSO marked 1,294 dangerous objects, marked 831 dangerous territories and helped remove 37,629 mines and pieces of UXO. ${ }^{6}$ Other parties involved in such activities include the Royal Moroccan Army, the Mauritanian government, and concerned nongovernmental organizations such as the UK-based Landmine Action. In 2006 Landmine Action taught an ordnance-disposal training program to 12 Polisario engineers, all of whom have since graduated and begun destroying mines. ${ }^{4}$

Isolating and eliminating the mine threat is an important step toward making the territory inhabitable and peaceful. One of the most noteworthy mine-clearance operations in Western Sahara took place in May 2001 when the RMA destroyed 3,000 anti-tank and 37,000 anti-personnel mines. ${ }^{7}$ In May 2006, MINURSO improved the marking of mineladen sites by constructing 450 warning signs. ${ }^{6}$ Though many Western Saharan minefields still await marking and fencing and destruc-

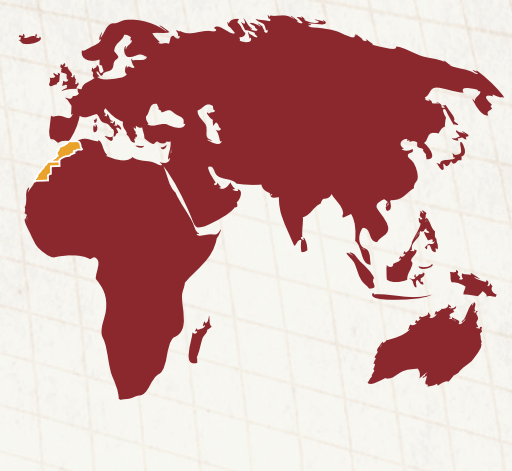

tion, the country's stockpiles have been nearly demolished. Over 300 international visitors attended the Polisario's destruction of the final 3,321 AP mines in its stockpile in February 2007. ${ }^{8}$ Morocco has retained a small quantity of AP mines as an educational tool. ${ }^{6}$

\section{Dispute Settlement}

Morocco and the Polisario have met on multiple occasions to resolve their issues. The second attempt at such an agreement in 2003 failed to satisfy Morocco. ${ }^{9}$ In August 2007 the United Nations provided a two-day retreat with researched presentations for the two sides to negotiate a resolution, but parties were ultimately unable to arrive upon an agreeable peace plan. ${ }^{10}$ The prospect of peace is an important step toward full mine clearance and elimination in Western Sahara. Moroccans, the Polisario, and Algeria-based refugees all depend on mine-action groups to cleanse Western Sahara so that they can one day safely inhabit the region again.

See Endnotes, page 113
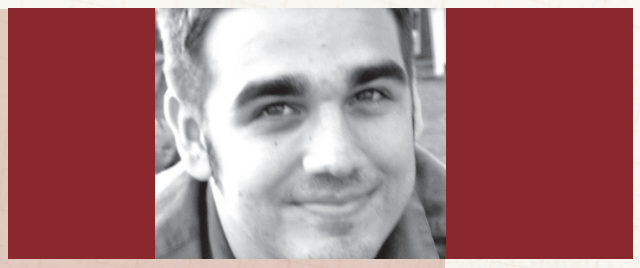

Chad McCoull joined the Journal of Mine Action in January 2007 as an Editorial Assistant. He is currently a technical and scientific communication major at James Madison University. He is pursuing a concentration in online publications and a minor in writing and rhetoric.

Chad McCoull Editorial Assistant Journal of Mine Action Mine Action Information Center E-mail:maic@jmu.edu 